BNL 19042

\author{
BROOKHAVEN NAT IONAL LABORATORY \\ Associated Universities, Inc. \\ Upt on, New York \\ ACCELERATOR DEPARTMENT \\ Informal Report
}

\title{
RANDOM ERROR MULTIPOLES IN SUPERCONDUCTING COSINE \\ AND WINDOW-FRAME DIPOLES
}

G. Parzen

June 28,1974

\section{ABSTRACT}

The random error multipoles in the median plane magnetic field, as measured in the two superconducting $8 \mathrm{~cm}$ cosine magnets, ISA I and ISA II, and in the two $8^{\circ}$ bend superconducting window-frame magnets, are compared with each other and with the results of theoretical calculations.

This teport was prepared as yn account of work
sponsored by the United States Government. Neither
the United States nor the United States Atomic Energy
Commission, nor any of their employees, nor any of
their contractors, subcontractors, or their employees,
makes any warranty, express or implied, or assumes any
legal liability or responsibility for the accuracy, com-
pletersess or usefulness of any information, apparatus,
product or process disclosed, or represents that its use
would not infringe privately owned rights.

\section{NOT I C E}

This report was prepared as an account of work sponsored by the United States Government. Neither the United States nor the United States Atomic Energy Commission, nor any of their employees, nor any of their contractors, subcontractors, or their employees, makes any warranty, express or implied, or assumes any legal liability or responsibility for the accuracy, completeness or usefulness of any information, apparatus, product or process disclosed, or represents that its use would not infringe privately owned rights. 
Experimental measurements have been made of the random error multipoles present in two identical cosine magnets, ${ }^{1}$ the $8 \mathrm{~cm}$ models ISA I and ISA II, and in two identical window-frame magnets, ${ }^{2}$ which are part of the $8^{\circ}$ bend system. These measurements can be compared with the results of theoretical calculations of the random error multipole present in cosine magnets ${ }^{3}$ and in window-frame magnets ${ }^{4}$ due to a random error in the position of the current blocks of $0.005 \mathrm{~cm}$.

This comparison is shown in Fig. 1, where the error multipoles in the radial component of the magnetic field in the median plane, a $n$, are plotted Egainst $n$. The $a_{n}$ are defined by witing the median plane radial field as

$$
B_{r}=B_{0}\left(a_{0}+a_{1} x+a_{2} x^{2}+\ldots\right),
$$

where $B_{0}$ is the unperturbed field of the dipoles. In order to make the comparison easier, the results for the cosine magnets, which have a radius to the inner coil surface of $4 \mathrm{~cm}$, were scaled to those of a cosine magnet with a radius of $5 \mathrm{~cm}$. In the $8^{\circ}$ bend window-frame magnels, the inner surface of the coil is $5 \mathrm{~cm}$ from the center.

The solid 1 ines in Fig. 1 are the computed results for the cosine and window-frame magnets. They indicate that the higher multipoles present in the window-frame are considerably smaller than those of the cosine magnet. This can be understood by realizing that the $a_{n} \sim 1 / R^{n+1}$ where $R$ is some effective radius of the coils, and that the effective $R$ of the window-frame magnet is $\sqrt{2}$ times larger than the effective $R$ of the cosine magnet. The theoretical results should be treated with caution, since the assumption of the theoretical calculation for the window-frame magnet that each of the 4 current blocks moves as a whole is probably not valid and is worse for the higher multipoles.

The experimentally measured results are also shown in Fig. 1 as crosses for the cosine magnet and circles for the window-frame magnet. The experimental

1. W.B. Sampson, P.F. Dah1, A.D. McInturff, and R.E. Robins, Proc. Ix Intern. Conf. High-Energy Accelerators, SLAC (1974).

2. J. Allinger, G. Danby, B. DeVito, H. Foelsche, S. Hisieh, J. Jackson, and A. Prode11, Proc. IX Intern. Conf. High-Energy Accelerators, StAC (1974).

3. P.F. Dahl, BNL Report CRISP 73-2 (1973); G. Parzen, BNL Report AND-187 (1972).

4. G. Parzen and K. Jellett, BNL Report MAD 73-12 (1973). 


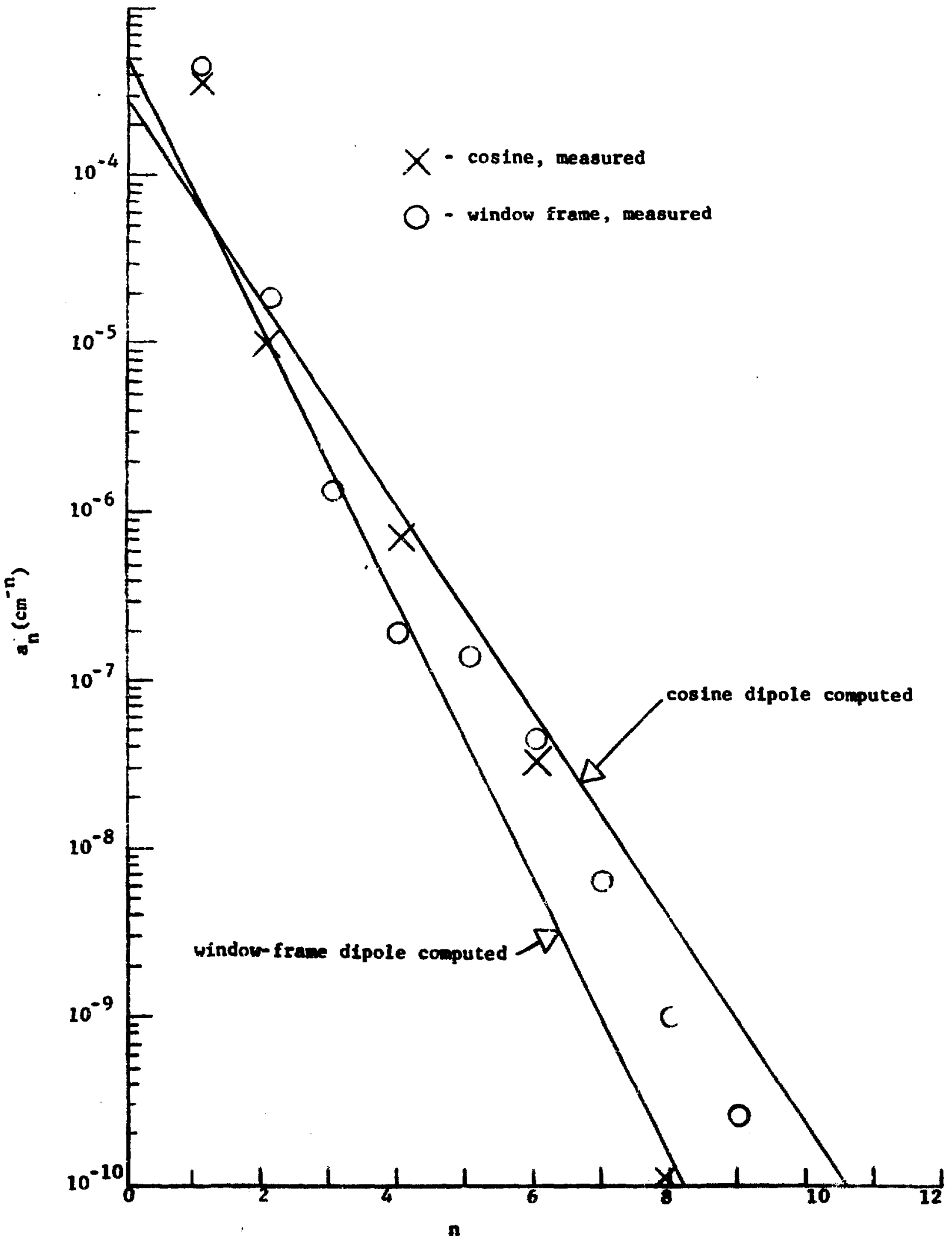

IL) 1 
results for the $a_{n}$ vary with the level of field excitation of the dipoles, and are somewhat differen for the two models of each magnet. Also, in some cases, the origin of the $a_{n}$ is thought to be innown and these may not be considered as due to random errors. The experimental results show on the graph are the largest values measured for the $a_{n}$, as one changes the field level and for the two models. This gives a pessimistic estimate of the multipoles present.

The agreement of the measurement with theory seems reasonable. One can expect rather large deviations since the theoretical result is an cus result, and a particular measurement can give results differing considerably from the rms result. With the 1 imited experimental. results available, one might conclude that the random error multipoles present for the cosine and window-frame dipoles are about equal, and this is roughly true even for the higher multipoles.

GP:ph

$6 / 28 / 74$

Distr.: AADD External 